American Journal of Economics and Business Administration 2 (4): 360-365, 2010

ISSN 1945-5488

(C) 2010 Science Publications

\title{
The Ethical and Non Ethical Mutual Funds Comparison
}

\author{
${ }^{1}$ Rosa Adamo, ${ }^{2}$ Angela Coscarelli, ${ }^{1}$ Domenica Federico and ${ }^{1}$ Antonella Notte \\ ${ }^{1}$ Department of Business, \\ ${ }^{2}$ Department of Economics and Statistics, \\ University of Calabria, Italy
}

\begin{abstract}
Problem statement: One of the astonishing new developments in the financial community is the rise of ethical investments during the last decade. Particularly, the recent financial crisis has determined a major attention towards an ethically oriented finance based on social investments and environmental benefits that can create greater corporate crisis prevention. Because of the sheer size and importance of the ethical mutual funds, we thought to compare the ethical and non ethical mutual funds. Approach: The aim of this study was to describe the ethical and non ethical mutual funds under Italian and foreign law highlighting how some factors, such as performance, typology (equity, balanced, fixed income), geographic location, management fees, characterize these funds in different way. Results: The analysis has been carried out collecting a data set of 219 mutual funds published on www.morningstar.com. The data set is subdivided in 109 ethical mutual funds and 110 non ethical mutual funds. The study uses a multi-disciplinary approach and it is led by a Multiple Correspondence Analysis (MCA) which puts in evidence the principal characteristics of the mutual funds by their projection on a factorial plane. Later the multivariate analysis carries out typologies of mutual funds clusters with particular characteristics by a Cluster Analysis. The study confirmed the existence of different characteristics with reference to the ethical and non ethical mutual funds. Particularly, it puts in evidence three groups of funds which are inside homogeneous but heterogeneous between them by the characteristics considered. The first groups, defined "negative ethical performance", is composed of 152 funds. The second groups, named "positive non ethical performance", is characterized by non ethical fund (50.23\% of them is present in this group). The third cluster is called "young funds" and it is composed of funds born in the period 2005-2008. Conclusion: Finally, the results indicated that the ethical funds are different from the non ethical funds with regards to the performance and put in evidence that the ethical funds governed the financial crisis triggered by subprime in a better way than the non ethical funds. Consequently we argue that it is important that the interests of the financial community are addressed to the development and promotion of ethically oriented finance and of its instruments.
\end{abstract}

Key words: Mutual funds, ethical mutual funds, multivariate analysis

\section{INTRODUCTION}

The mutual fund industry has decreased dramatically over the last years, particularly during the financial global current crisis. In this contest, one of the astonishing new developments in the financial community is the rising of social and ethical investments.

During the last years, the Socially Responsible Investment (SRI) had the greatest attention among investors and financial intermediaries. The social investment includes activities, as social screening (e.g., ethical mutual funds), community investment (e.g., investment in local development initiatives) and shareholder activism (e.g., shareholder resolutions or active dialogue with companies). The activity of social screening and particularly of ethical mutual funds is the most popular of these social investment categories.

The ethical mutual funds do not invest in companies that have a low rating or are not considered ethically-oriented by the fund managers (Adamo, 2009; Becchetti and Fucito, 2000; Beltratti and Miraglia, 2001). The ethical mutual funds are similar instruments to ordinary mutual funds, not only for the management structure but also for the financial and regulatory aspects. Particularly, the ethical funds can be distinguished according to the usual classifications applied to traditional asset management products

Corresponding Author: Rosa Adamo, Department of Business, University of Calabria, Italy 
(securities and real estate, opened and closed, equities, balanced, liquid and flexible).

However, they differ from the traditional mutual funds in the selecting investments process to be included in the portfolio. In fact, all ethical mutual funds use a series of screens or filters to either intentionally avoid (e.g., exclusionary or negative screens) and/or intentionally select (e.g., qualitative or positive screens) certain companies as part of the fund's portfolio (Cory, 2001; Lanza et al., 2003; Vigano, 2001).

Many funds avoid investing in companies involved in tobacco, alcohol, gambling, military, firearms, or nuclear weapons. Others focus on social issue screens, such as avoiding companies connected with child labor or that fail to respect animal rights, gay and lesbian rights, diversity, or feminism. Other possible screens might include selecting companies that best support the community, diversity, employee relations, environment, or product quality and safety (Kinder and Domini, 1997).

The ethical mutual funds have grown significantly over the past two decades. In 2007, according to Eurosif research, the total asset under management in Europe has reached 2.665 trillion of Euros. This total amount is made up of 511.7 billion of Euros for Core SRI and 2.154 trillion of Euros for Broad SRI (The Core SRI is composed of the following strategies: the ethical exclusions (more than two negative criteria applied), the positive screening, including Best-in-Class and SRI theme funds and the combination of ethical exclusion and positive screening. The Broad SRI is composed of the following strategies: The simple screening, including norms-based screening (up to two negative criteria), the engagement and the integration). The European market of ethical funds has increased from 1.033 trillion of Euros in 2005-2.665 trillion of Euros at the end of 2007. On a like-for-like basis 10 , this represents a growth of $102 \%$ over two years (Eurosif, 2008).

In Italy, the ethical funds are still a small portion of total assets under management. In 2007, the Core SRI accounts of about 3.4 billion of Euros, while the Broad SRI reaches 240 billion of Euros.

The aim of this study is to describe the ethical and non ethical mutual funds under Italian and foreign law highlighting if some factors, such as performance, typology (equity, balanced, fixed income), geographic location, management fees, characterize these funds in different way.

The analysis has been carried out by collecting a data set of 219 mutual funds published on www.morningstar.com. The data set is subdivided in
109 ethical mutual funds and 110 non ethical mutual funds. The study uses a multi-disciplinary approach and it is led by a MCA which puts in evidence the principal characteristics of the mutual funds by their projection on a factorial plane. Later it carries out typologies of clusters of mutual funds with particular characteristics by a Cluster Analysis.

General market overview: The overall Italian funds industry has suffered massive outflows in the last years (-120 billion of Euros from 2006 to first quarter 2008). Funds account for less than $10 \%$ of total financial wealth of Italian families and about $20 \%$ of the Italian Growth National Product.

The ethical mutual funds are of no exception. In 2007, the Core SRI accounts for about 3.4 billion of Euros, which means $0.32 \%$ of total assets under management to national level. The growth rate respect to 2006 for the Core SRI is equal to $23 \%$. The Broad SRI has increased remarkably: from 0.09 billion of Euros in 2005-240 billion of Euros in 2007.

The prevalence of the retail component, as opposed to the institutional one, in the Italian SRI market still sets it apart from other markets. Unlike other European markets, the institutional investor market is still very small (6\% of total Core SRI) due to the relatively recent beginning of the pension system (second and third pillars).

The most employed SRI strategy is a combination of negative screening (basically sector exclusion) and Best-in-Class. SRI thematic funds have been introduced recently and have done well in terms of inflows, reaching 1.5 billion of Euros of assets under management.

The engagement is still a niche phenomenon, due to the small assets amounts, relatively recent beginning of the active exercise of voting rights by Italian asset managers and lack of large independent asset managers. However, a recent regulation jointly issued by the Bank of Italy and Consob (the market authority) encourages them to define and implement consistent voting policies and strategies for investor interests.

The ethical and non ethical mutual funds: Comparing the ethical and non ethical mutual funds we construct a database containing the two different typologies of mutual funds under Italian and foreign law.

The data are collected by www.morningstar.com and they are related to some funds characteristics such as typology, geographic location, management fees, performance.

Fig. 1 shows the sample of the funds by the inception date. 
Am. J. of Economics and Business Administration 2 (4): 360-365, 2010

Table 1: The ethical and non ethical funds management fee

\begin{tabular}{lll}
\hline & Ethical funds (\%) & Non ethical funds (\%) \\
\hline Average & 1.18 & 1.43 \\
Dev_st & 0.56 & 0.67 \\
Min & 0.00 & 0.20 \\
Max & 2.39 & 3.65 \\
Asymmetry & -75.60 & 83.10 \\
\hline
\end{tabular}

Table 2: The ethical and non ethical funds performances

\begin{tabular}{|c|c|c|c|c|c|c|c|}
\hline & 1 month & 3 months & 6 months & 1 year & 3 years & 5 years & 10 years \\
\hline \multicolumn{8}{|c|}{ Ethical funds } \\
\hline Average & -6.54 & -3.18 & -14.82 & -19.50 & 0.32 & 4.87 & 0.64 \\
\hline Dev_st & 4.16 & 3.14 & 7.36 & 11.87 & 3.47 & 3.66 & 2.15 \\
\hline Min & -16.72 & -13.55 & -28.52 & -44.54 & -9.77 & -2.54 & -3.29 \\
\hline Max & 12.49 & 4.59 & 0.39 & 24.52 & 9.51 & 14.04 & 3.81 \\
\hline Asymmetry & 0.80 & -0.77 & 0.76 & 0.87 & -0.22 & 0.44 & -0.42 \\
\hline \multicolumn{8}{|c|}{ Non ethical funds } \\
\hline Average & -0.87 & -8.13 & -11.76 & -18.20 & -5.38 & -0.27 & 0.12 \\
\hline Dev_st & 2.23 & 10.72 & 16.28 & 20.83 & 6.87 & 2.64 & 3.05 \\
\hline Min & -8.18 & -33.43 & -49.02 & -53.60 & -20.66 & -6.85 & -5.85 \\
\hline Max & 2.50 & 6.92 & 15.16 & 11.33 & 3.70 & 6.85 & 3.52 \\
\hline Asymmetry & -0.78 & -0.38 & -0.23 & -0.19 & -0.27 & -0.02 & -0.77 \\
\hline
\end{tabular}

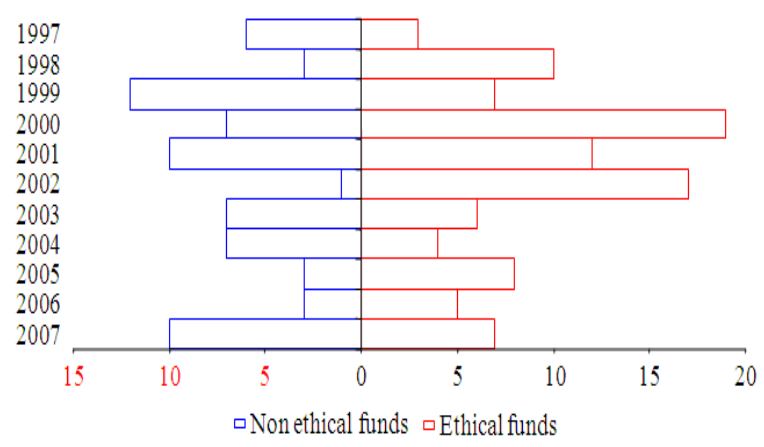

Fig. 1: The pyramid of the mutual funds classified by the inception date

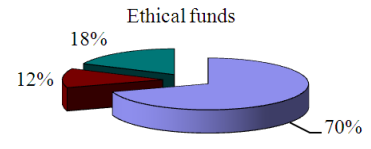

口Equity $\mathbf{a}$ Balanced $\mathbf{\square}$ Fixed income

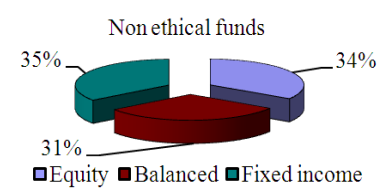

Fig. 2: The categories of mutual funds

As regards the ethical sector, it is represented by 109 funds and it is divided into different categories indicated by Assogestioni: Equity (76), balanced (13) and fixed income (20). As regards the non ethical sector, it is representative by 110 funds and it is based on the following categories: Equity (37), balanced (34) and fixed income (39) (Fig. 2).

The asset of the ethical funds is on equal average to 275,96 million of Euros, while the asset of the non ethical funds is on equal average to 156,04 million of Euros.

The management fees of the ethical funds are equal to $1.18 \%$; however there are some funds with
$2 \%$ exceeding value (Table 1). Moreover, the index of asymmetry (this indicator allows to detect a distribution that cannot be separated by a vertical axis into two equal speculation. A positive value indicates a distribution that extends towards more positive values, while a negative value indicates a distribution that extends to more negative values) shows negative values and indicates an extending distribution to very low amounts. The management fees by the non ethical funds are on higher average $(1.43 \%)$ and present a max equal value to $3.65 \%$. In this case the index of asymmetry is positive hence the distribution extends towards more positive values.

Data of the performance are published on www.morningstar.com. Specifically, the performance recorded by the ethical and non ethical funds on 30 December 2008, related to 1, 3 and 6 months, 1, 3, 5 and 10 years of their beginning, are collected and revised to determine some statistical indicators.

Particularly, it is noted the performance on average registered by the traditional funds is better than that registered by the ethical funds and the minimum and maximum values are registered on a 1 year (Table 2).

\section{MATERIALS AND METHODS}

The study uses a multi-disciplinary approach (Bauer et al., 2005; Guerard, 1997; Gray, 2002). Particularly, it is led by a Multivariate Analysis applying a MCA, which puts in evidence the principal characteristics of the mutual funds by their projection on the factorial plane and a Cluster Analysis to carry out typologies with particular characteristics of mutual funds (Corbetta, 2002; Fabbris, 1997). 
The MCA is an extension of Correspondence Analysis (CA) which analyzes the pattern of relationships of several categorical dependent variables. As such, it can also be seen as a generalization of Principal Component Analysis (PCA) when the variables to be analyzed are categorical instead of quantitative.

Because of the widely varying countries and languages in which these typologies of methods have been proposed, there is a wide variety of names for what turns out to be just one method. It is the American Optimal Scaling, Optimal Scoring and Appropriate Scoring methods; the Canadian Dual Scaling; the Dutch Homogeneity Analysis; the French MCA; the Israeli Scalogram Analysis and the Japanese Quantification Method. In addition to the several countries and languages, MCA has been proposed many times because the data analyzed can be expressed in several apparently different but equivalent ways. MCA can be seen as a way of analyzing a subject by variable matrix with categorical variables; or a subject by item matrix of multiple-choice data; or a multi-way contingency matrix (De Leeuw, 2007).

Technically MCA is obtained by using a standard $\mathrm{CA}$ on an indicator matrix (i.e., a matrix whose entries are 0 or 1$)$. The percentages of explained variance need to be corrected and the CA interpretation of inter point distances needs to be adapted.

MCA is used to analyze a set of observations described by a set of nominal variables. Each nominal variable includes several levels and each of these levels is coded as a binary variable. For example gender (F Vs $\mathrm{M})$ is one nominal variable with two levels. The pattern for a male respondent will be 01 and 10 for a female. The complete data matrix is composed of binary columns with only one column taking the value " 1 " per nominal variable.

MCA can also accommodate quantitative variables by recoding them as "bins". For example, a score with a range of $-5-+5$ could be recoded as a nominal variable with three levels: less than 0 , equal to 0 , or more than 0 . With this schema, a value of 3 will be expressed by the pattern 001 . The coding schema of MCA implies that each row has the same total, which for CA implies that each row has the same mass.

The Cluster Analysis is concerned by forming groups of similar objects based on several measurements of different kinds made on the objects. The key idea is to identify classifications of the objects that would be useful for the aims of the analysis. This idea has been applied in many areas including astronomy, archeology, medicine, chemistry, education, psychology, linguistics and sociology.
In this study we have used a hierarchical cluster analysis and a Ward's linkage to find relatively homogeneous clusters of cases based on measured characteristics.

It starts with each case in a separate cluster and then it combines the clusters sequentially, reducing the number of clusters at each step until only one cluster is left.

When there are $\mathrm{N}$ cases, this involves $\mathrm{N}-1$ clustering steps, or fusions. This hierarchical clustering process can be represented as a tree, or dendrogram, where each step in the clustering process is illustrated by a join of the tree.

The initial data for the hierarchical cluster analysis of $\mathrm{N}$ objects is a set of $\mathrm{N}$ per $(\mathrm{N}-1) / 2$ object-to-object distances and a linkage function for computation of the cluster-to-cluster distances.

A linkage function is an essential prerequisite for hierarchical cluster analysis. Its value is a measurement of the "distance" between two groups of objects (i.e., between two clusters). Algorithms for hierarchical clustering normally differ by the linkage function used. The most common type of linkage functions give rise to the following algorithms for Cluster Analysis: Single linkage clustering; complete linkage clustering; average linkage clustering; average group linkage; Ward's linkage.

In our study we have used this last-one. The idea has much in common with Analysis Of Variance (ANOVA). The linkage function specifying the distance between two clusters is computed as the increase in the "Error Sum of Squares" (ESS) after fusing two clusters into a single cluster. Ward's Method seeks to choose the successive clustering steps to minimize the increase in ESS at each step.

\section{RESULTS}

The MCA allows to analyze the pattern of relationships of several categorical dependent variables (Bolasco, 1999).

As regards our study, it puts in evidence two factors that explain the $27.05 \%$ of the inertia (Table 3 ).

Table 3: Eigen-values, percentage of inertia and cumulative percentage

\begin{tabular}{lll}
\hline Eigen-values & Percentage of inertia & Cumulative (\%) \\
\hline 0.33 & 15.40 & 15.40 \\
0.25 & 11.65 & 27.05 \\
0.23 & 10.55 & 37.60 \\
0.13 & 6.04 & 43.64 \\
0.11 & 4.92 & 48.56 \\
\hline
\end{tabular}


Am. J. of Economics and Business Administration 2 (4): 360-365, 2010

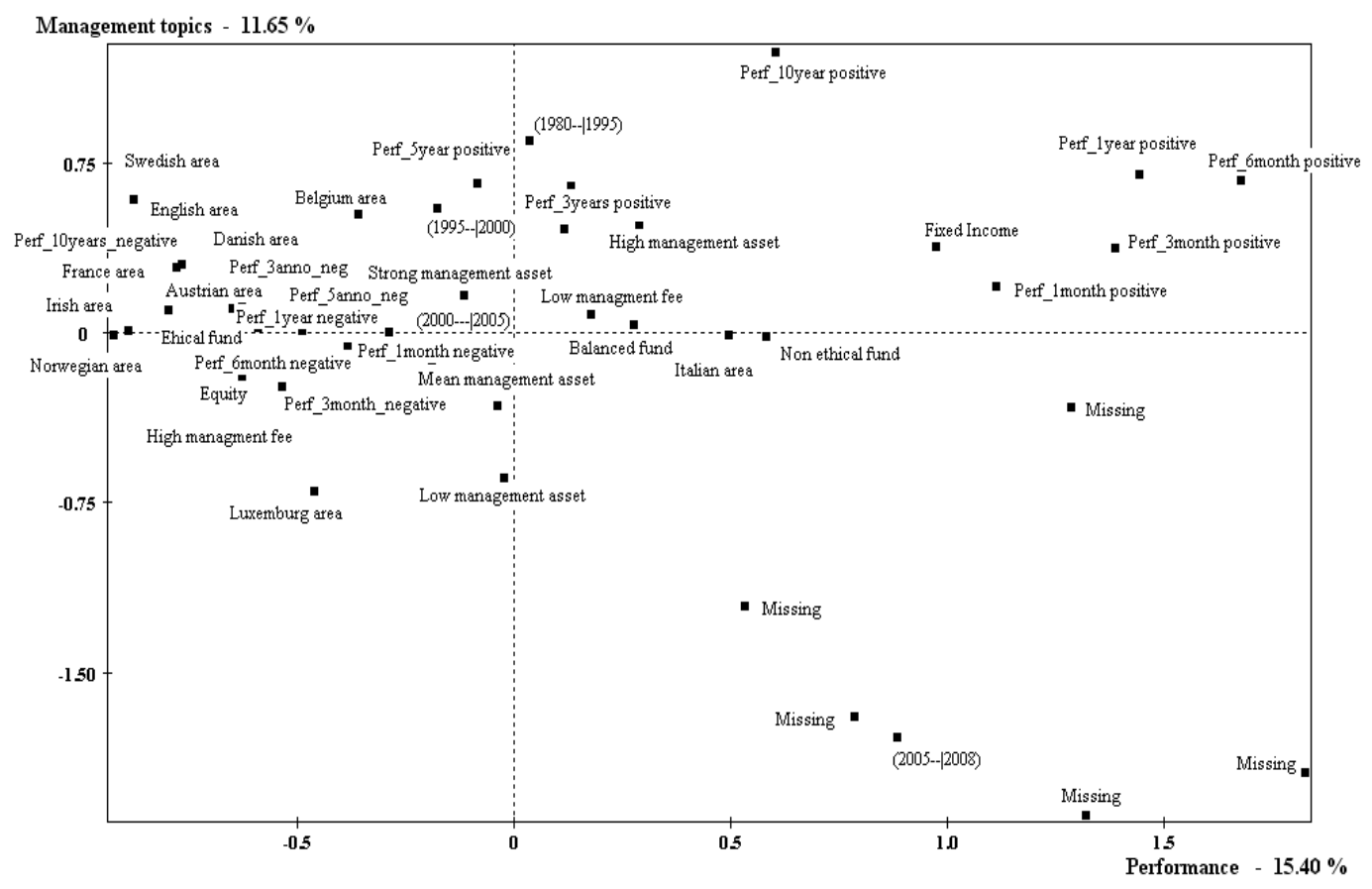

Fig. 3: MCA of the ethical and non ethical fund

About the first factor, defined "performance", the modalities that contribute to its construction are linked to the performance. This variable is like a leadership by which it is possible to explain the other variables: the typology and the geographic location. Particularly, on the positive side of the first factor there are the non ethical fixed income funds with a positive performance, while on the opposite side there are the ethical equity funds characterized by a negative performance. In this case, it deals with English, France, Danish, Austrian, Irish, Norwegian funds.

The second factor, defined "management topics", is explained by the variables linked to the management asset, the management fees and the inception date. On the positive side there are funds characterized by high management asset, particularly for the funds with inception date in 1980-1995, while on the opposite side there are the other funds which have a high management fee and a low management asset, too.

In the Fig. 3 we can note the contribution of the individual modalities of the variables as regards the two factors.

The analysis continues by a clustering methodology that puts in evidence three groups of funds which are inside homogeneous but heterogeneous between them by the characteristics considered, determining a gain of inertia inter-cluster/total from 0.42-0.43\% (Bolasco, 1999).
The first cluster, defined "negative ethical performance", is composed of 152 funds and it is exclusive because the $98.6 \%$ of the funds with negative performance at 6 months are present in this group. Besides, the same cluster is exclusive for the presence of ethical funds (68\%), prevalently derived by Italian and England geographical zones. For the $63 \%$ of them it deals with equity funds.

The second cluster, named "positive non ethical performance", is characterized by non ethical fund (50.23\% of them is present in this group) and in this cluster there are the $90 \%$ of the non ethical fund which have a very positive performance to 3 months. It deals with Italian fixed income funds (55.2\%).

At the end, the third cluster is called "young funds". It deals with funds born in the period 20052008; the trend of their performance is not known and the management fees are not very expensive.

\section{DISCUSSION}

The aim of this study was to describe the ethical and non ethical mutual funds under Italian and foreign law highlighting how. Particularly, the ethical funds performance decreased smaller than the traditional funds performance.

Some recent studies (Ardu, 2008; Delbecque, 2008; Eurosif, 2008; Pezzatti, 2008) confirm these 
observations and show how the ethical funds governed the financial crisis triggered by subprime in a better way than the non ethical funds.

By the statistical analysis was confirmed the existence of different characteristics with reference to the ethical and non ethical mutual funds. Particularly, the multivariate analysis allowed to put in evidence some groups of mutual funds through significant statistical results.

Indeed, this study confirmed previous theoretical analysis over more it was possible to identify groups of funds with more features according to an analysis statistically significant.

\section{CONCLUSION}

The results of the analysis lead to two considerations.

Firstly, the analysis showed that the ethical funds are different from the non ethical funds with regards to the performance and so they are included in two separate clusters. Indeed, the observations on the performance of these two clusters revealed more positive values for the traditional mutual funds compared to the ethical funds. This is more evident because of our sample is composed predominantly by Italian equity funds. In the cluster defined "negative ethical performance" a lot of ethical equity funds are placed in Italy. Particularly, many Italian ethical equity funds focus only on negative criteria to avoid investing in companies involved in tobacco, alcohol, gambling, military, firearms, or nuclear weapons; they do not use positive criteria to select companies that best support community, diversity, employee relations, environment, or product quality and safety.

Secondly, data of the third cluster, called "young funds", show the tendency of the management company to reduce the management fees in recent years trying to make welcome again the asset management market.

\section{REFERENCES}

Adamo, R., 2009. The Ethical Finance: Principles, Tools and Purpose. 1st Edn., ESI, Italy, pp: 202.

Ardu, B., 2008. Advisor esterni, pagelle alle aziende così i fondi etici battono la crisi. ARCHIVIO LA REPUBBLICA DAL. http://ricerca.repubblica.it/repubblica/archivio/repu bblica/2008/10/25/advisor-esterni-pagelle-alleaziende-cosi-fondi.html

Bauer, R., K. Koedijk and R. Otten, 2005. International evidence on ethical mutual fund performance and investment style. J. Bank. Finance, 29: 1751-1767. DOI: $10.1016 /$ j.jbankfin.2004.06.035
Becchetti, L. and L. Fucito, 2000. La Finanza etica: Considerazioni teoriche e simulazioni empiriche. Riv. Polit. Econ., 5: 29-67. http://www.rivistapoliticaeconomica.it/pdf/maggio/ 02becche.pdf

Beltratti, A. and R. Miraglia, 2001. Mutual Funds, the Italian Case. 1st Edn., Carocci Editore, Italy, pp: 180.

Bolasco, S., 1999. Analisi Multidimensionale dei Dati. Metodi, Strategie e Criteri D'interpretazione. 1st Edn., ISBN: 8843014013, pp: 355.

Corbetta, P., 2002. Metodi di Analisi Multivariata per le Scienze Sociali. 1st Edn., Copyleft University, Il Mulino, ISBN: 978-88-15-08501-6, pp: 360.

Cory, J., 2001. Business Ethics. 1st Edn., Kluwer Academic Publishers, USA., ISBN: 0792373006, pp: 277.

De Leeuw, J., 2007. Correspondence analysis of archeological abundance matrices. UCLA Statistic Electronic Publications. http://escholarship.org/uc/item/3m18x7qp

Delbecque, B., 2008. Trends in the European Investment Fund Industry in the Fourth Quarter of 2008 and Results for the Full Year 2008. EFAMA Q. Stat. Release, 36: 1-11. http://www.efama.org/index2.php?option=com_do cman\&task=doc_view \&gid=872 \&Itemid $=35$

Eurosif, 2008. European SRI study. Eurosif. http://www.eurosif.org/publications/sri_studies

Fabbris, L., 1997. Statistica Multivariata-Analisi Esplorativa Dei Dati. 1st Edn., McGraw-Hill, Italy, ISBN: 9788838607653, pp: 438.

Gray, R., 2002. The financial performance of European ethical funds 1996-1998. J. Account. Finance, 1: 3-22. http://eprints.gla.ac.uk/15758/

Guerard, Jr., J.B., 1997. Is there a cost to being socially responsible in investing? J. Invest., 16: 475-490. DOI: $10.1002 /($ SICI)1099131X(199712)16:7<475::AID-FOR668>3.0.CO;2-X

Kinder, P.D. and A.L. Domini, 1997. Social screening: Paradigms old and new. J. Invest., 6: 12-16.

Lanza, S., M. Calcaterra and F. Perrini, 2003. Etica Finanza e Valore D'impresa. 1st Edn., EGEA, Italy, ISBN: 8823807557, pp: 320.

Pezzatti, F., 2008. Etica Sgr stands and points to the institutional. Il Sole.

Vigano, L., 2001. La Banca Etica. Esperienze in Italia e All'estero, Strategie. e Innovazione Nelle Scelte Operative. 1st Edn., Bancaria Editrice, Italy, ISBN: 978844901943, pp: 220. 